\title{
A note: an approach to estimate efficiency of energy utilization for milk production
}

\begin{abstract}
A. Chwalibog
The Royal Veterinary and Agricultural University, Department of Animal Science and Animal Health Bülowsvej 13, 1870 Frederiksberg $C$, Denmark
\end{abstract}

(Received 8 December 1994; accepted 16 February 1995)

\begin{abstract}
Data from 9 balance experiments with lactating Jersey cows was used to cvaluatc the energetic efficiency of metabolizable energy utilization for milk production $(\mathbf{k l})$. It has been demonstrated that $\mathrm{kl}$ values differ depending on the proportion between energy retained in fat (LFE) and protein (LPE) in milk. A new approach to calculate $\mathrm{kl}$ values according to the equation $\mathrm{kl}=0.510+0.052 \times \mathrm{LFE} / \mathrm{LPE}$ is presented.
\end{abstract}

KEY WORDS: metabolizable energy utilization, energetic efficiency, lactation, milk composition, dairy cow

\section{INTRODUCTION}

Metabolizable energy available for energy deposition in milk is used for retention in fat, protein, and carbohydrate in proportions varying upon genetic and nutritional factors. Since there are major differences between energy utilization for protein and fat formation, it has previously been suggested that partial efficiencies for milk energy components should be used instead of a total efficiency of energy deposition in milk (Chwalibog, 1991). However due to homogenous relation between protein and carbohydrate retention and the total energy retention in milk, the multiple regression models, as applied for growing animals, do not provide biologically cogent estimates of the partial efficiencies. Therefore, in the present paper a new approach to evaluate energy utilization for milk production is described. 


\section{MATERIAL AND METHODS}

The data used in the present calculations included measurements carried out with 2 Jersey cows between 5 th and 16 th week of the 2 nd lactation. The results from 9 individual balance periods, each consisting of a 14 days quantitative collection of excreta and milk combined with two $24 \mathrm{~h}$ respiration experiments, have been used.

The cows were fed to appetite with a concentrate mixture, dried sugar beet pulp with molasses, grass pellets and barley straw (Table 1). Feeding and sampling procedures, chemical analyses and gas exchange measurements (indirect calorimetry) were the same as described for previous experiments by Chwalibog (1991).

The total energy deposition in milk (LE) was measured by a bomb calorimeter method. In order to calculate the amount of energy deposited in protein (LPE), fat (LFE) and carbohydrate (LCE) in milk and the proportions LPE/LE, LFE/LE and LCE/LE the enthalpies of $23.8,38.9$ and $16.3 \mathrm{~kJ} / \mathrm{g}$ protein, fat and carbohydrate (Chwalibog, 1991), were used respectively. In order to calculate the efficiency of metabolizable energy (ME) utilization for energy retention in milk $(\mathrm{kl})$, a constant maintenance requirement $\mathrm{MEm}=450 / \mathrm{kg}^{0.75}$ and partial efficiencies of $\mathrm{ME}$ utilization $\mathrm{kf}=0.79$ for retained fat energy in the body (RFE) and $\mathrm{kp}=0.41$ for retained protein energy in the body (RPE) were applied according to Thorbek (1980). For negative energy balances ME was calculated as the sum of $\mathrm{ME}$ from feed and ME from mobilized body fat and protein with the above $\mathrm{kf}$ and $\mathrm{kp}$ values. The part of $\mathrm{ME}$ used for milk production was calculated by the substraction $\mathrm{ME}-\mathrm{MEm}-\mathrm{RPE} / \mathrm{kp}-\mathrm{RFE} / \mathrm{kf}=\mathrm{MEle}$. Then $\mathrm{kl}$ was calculated as the proportion LE/MEle.

\section{RESULTS}

The live weight of the cows was about $340 \mathrm{~kg}$ and the milk production was on average $22.1($ SEM $=0.33) \mathrm{kg} / \mathrm{d}$. The average $(\mathrm{n}=9)$ proportion of LPE/LE was $23.8(\mathrm{SEM}=0.45), \mathrm{LFE} / \mathrm{LE}$ was $52.5(\mathrm{SEM}=1.24) \%$ and $\mathrm{LCE} / \mathrm{LE}$ was 23.6 $(\mathrm{SEM}=0.59) \%$. Generally, protein constituted a higher and fat a lower part of LE than in previous experiments (Chwalibog,1991), indicating the nowadays preference to produce milk with increased protein but reduced fat content.

The individual results concerning ME partition and utilization are presented in Table 2. Despite the variation in $\mathrm{kl}$ values mirrored different proportions between $L E$ and MEle it was caused by different partition of LE between protein, fat and carbohydrate energy. Considering difficulties in estimation of partial efficiencies for energy retention in milk components, as discussed by Chwalibog 
TABLE 1

Chemical composition of feed compounds, $\mathrm{g}(\mathrm{MJ}) / \mathrm{kg}$ dry matter

\begin{tabular}{lccccccc}
\hline & $\begin{array}{c}\text { Dry } \\
\text { matter }\end{array}$ & Ash & $\begin{array}{c}\text { Crude } \\
\text { protein }\end{array}$ & $\begin{array}{c}\text { Crude } \\
\text { fat }\end{array}$ & $\begin{array}{c}\text { Crude } \\
\text { fibre }\end{array}$ & $\begin{array}{c}\text { N-frec } \\
\text { extractives }\end{array}$ & $\begin{array}{c}\text { Gross } \\
\text { energy }\end{array}$ \\
\hline Concentrates & 891 & 75.1 & 239 & 74.1 & 108 & 504 & 19.40 \\
Bcct pulp* & 892 & 86.8 & 104 & 9.5 & 140 & 660 & 16.79 \\
Grass pellets & 903 & 70.5 & 194 & 36.7 & 229 & 470 & 19.52 \\
Barley straw & 894 & 38.9 & 40 & 20.4 & 438 & 463 & 18.84 \\
\hline
\end{tabular}

* dried sugar beet pulp with molasses

TABLE 2 Individual measurcments of energy metabolism, $\mathrm{MJ} / \mathrm{d}$. Metabolizable energy (ME), retained or mobilized energy from body fat (RFE) and body protein (RPE), ME used for RFE and RPE (MEre), ME used for maintenance (MEm), encrgy retained in milk (LE), ME used for milk production MEle and energetic efficiency of ME utilization for energy retention in milk (kl)

\begin{tabular}{lrrrrrrrr}
\hline Lactation wcek & ME & RFE & RPE & MEre & MEm & LE & MEle & kl \\
\hline Cow 1 & & & & & & & & \\
5 & 171.6 & -13.90 & -0.10 & -17.77 & 36.02 & 87.05 & 135.6 & 0.64 \\
11 & 179.4 & 9.07 & 3.30 & 19.51 & 36.26 & 79.02 & 123.7 & 0.64 \\
13 & 184.2 & 9.82 & 3.71 & 21.48 & 35.87 & 80.61 & 126.8 & 0.64 \\
15 & 181.0 & 7.53 & 2.07 & 14.57 & 36.80 & 81.89 & 129.6 & 0.63 \\
Cow 2 & & & & & & & & \\
6 & 166.9 & -5.51 & 2.89 & 7.09 & 34.21 & 81.51 & 125.6 & 0.65 \\
10 & 169.8 & 5.76 & 3.36 & 15.48 & 34.92 & 74.41 & 119.4 & 0.62 \\
12 & 166.7 & -1.64 & 3.56 & 8.73 & 35.55 & 73.99 & 122.5 & 0.60 \\
14 & 174.9 & 8.84 & 1.91 & 15.81 & 35.55 & 74.58 & 123.5 & 0.60 \\
16 & 168.6 & 8.24 & 3.16 & 18.12 & 36.80 & 69.11 & 113.7 & 0.61 \\
\hline
\end{tabular}

(1991), an attempt has been made to describe a relationship between $\mathrm{kl}$ and the amount of energy retained in protein, fat and carbohydrate in milk. There was no significant relationship between LCE and $\mathrm{kl}$, probably due to a nearly constant LCE level during the period of lactation. However, as demonstrated in Figure 1, there was a linear relationship between $\mathrm{kl}$ and the proportion LFE/LPE.

The following regression was obtained:

$$
\begin{aligned}
& \mathrm{kl}=0.510+0.052 \times \mathrm{LFE} / \mathrm{LPE} \\
& \mathrm{SE} 0.0218 \quad 0.0097 \\
& \mathrm{n}=9, \mathrm{RSD}=0.081, \mathrm{CV}=1.29 \%, \mathrm{R}^{2}=0.804
\end{aligned}
$$




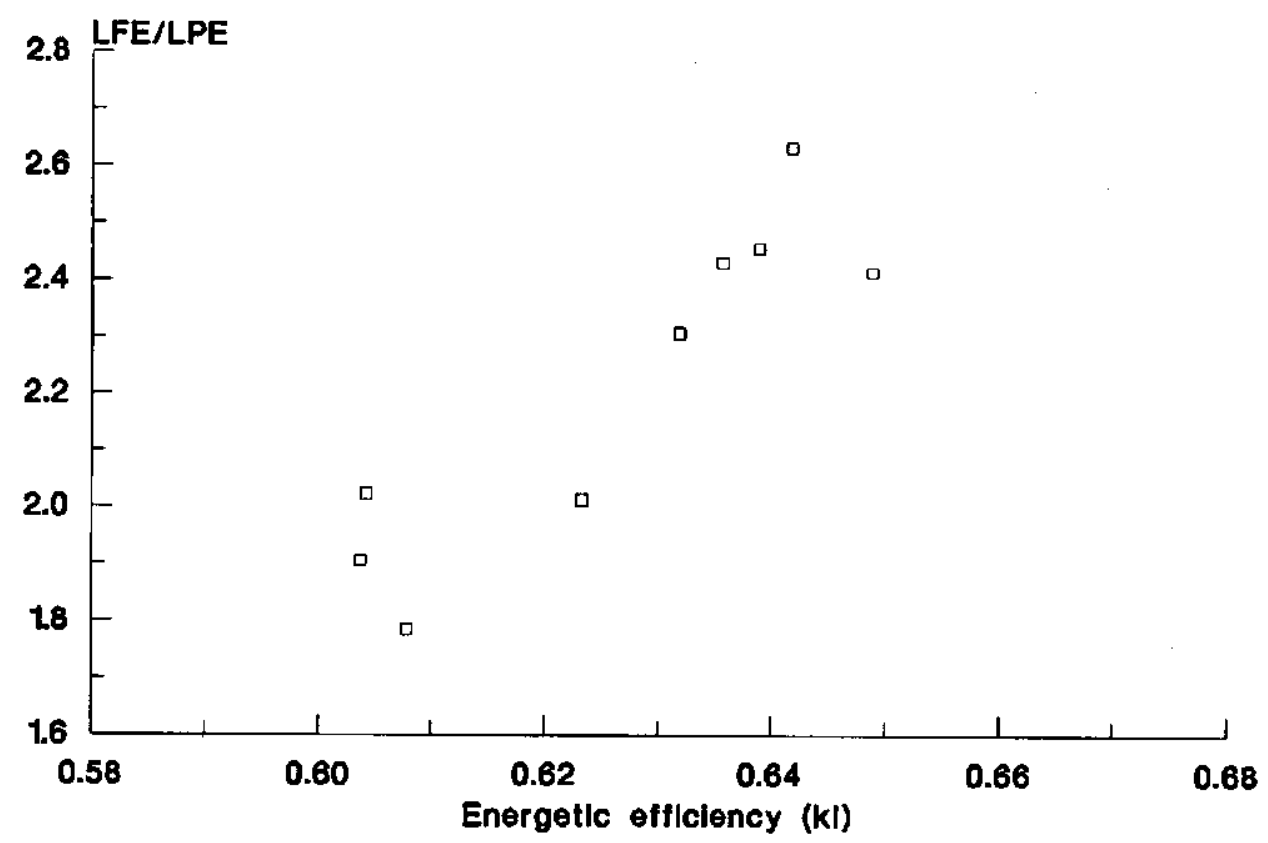

Figure 1. The proportion between energy retained in milk fat (LFE) and energy retained in milk protein (LPE) in relation to the energetic efficiency of ME utilization for cnergy retention in milk $(\mathrm{kl})$

The regression showed satisfactory fit between experimental data and the applied model with low $\mathrm{CV}$ and high $\mathbf{R}^{2}$ values. From this function the sum $0.510+0.052=0.562$ can be interpreted as the theoretical estimate of $\mathrm{kl}$ when $\mathrm{LFE}=\mathrm{LPE}$, i.e. $\mathrm{LFE} / \mathrm{LPE}=1$. Since in the present experiment the minimum value of LFE/LPE was 1.79 , and maximum was 2.63 the $\mathrm{kl}$ could be calculated to $0.510+0.052 \times 1.79=0.60$ and $0.510+0.052 \times 2.63=0.65$ for the extremes.

\section{CONCLUSIONS}

In our opinion the present approach is a good alternative for estimation of partial efficiencies for protein and fat retention in milk. In order to generalize the function of $\mathrm{kl}$ an extended data material is needed, but based on the present data it can be concluded that the total efficiency of energy retention in milk can be satisfactory used for predictions of energy requirements, provided it is described as a function of protein and fat content. 


\section{ACKNOWLEDGEMENT}

Financial support from the Danish Veterinary and Agricultural Council (13-3978) is gratefully acknowledged.

\section{REFERENCES}

Chwalibog A., 1991. J. Anim. Physiol. Anim. Nutr. 65, 206-218

Thorbek G., 1980. Report from the National Institute of Animal Science, Denmark, 498, pp. 104

\section{STRESZCZENIE}

Przyczynek do oznaczania wykorzystania energii na produkcję mleka

Oszacowano wydajność energetyczną wykorzystania energii metabolicznej do produkcji mleka (kl) na podstawic wyników 9 doświadczeń bilansowych przeprowadzonych na krowach dojnych rasy Jersey. Wykazano, że wartości kl zależą od stosunku pomiędzy energią zatrzymaną w tluszczu (LFE) i w biaku (LPE) mleka. Przedstawiono nowe założenie do obliczania wartości kl na podstawie równania $\mathrm{kl}=0,510+0,052 \times \mathrm{L} F \mathrm{FE} / \mathrm{LPE}$. 